\title{
EFEKTIVITAS PENGGUNAAN PENDEKATAN SLIM-N-BIL TERHADAP PEMAHAMAN KONSEP MATEMATIKA
}

\author{
INDRA MARTHA RUSMANA \\ indramartharusmana@ymail.com \\ Program Studi Pendidikan Matematika, Fakultas Teknik, Matematika, dan IPA \\ Universitas Indraprasta PGRI Jakarta
}

\begin{abstract}
Abstrak. Konsep matematika adalah salah satu dasar dalam mempelajari matematika, jika konsep yang diberikan kepada peserta didik tidak sampai dengan baik, maka hasil belajar dan pemahaman peserta didik pada materi akan berkurang. Konsep matematika dapat diberikan dengan berbagai pendekatan agar peserta didik mampu memahami materi yang diberikan guru, salah satu pendekatan pembelajaran matematik adalah SLIM-n-BIL. Tujuan penelitian ini yaitu untuk mengetahui pengaruh dan efektivitas dari penggunaan pendekatan Slim-n-Bil terhadap pemahaman konsep matematika peserta didik SMP. Penelitian ini menggunakan metode kuasi eksperimen yang dilaksanakan di SMP Mahardika dengan pengambilan data melalui soal essai. Pengujian hipotesis dilakukan dengan menggunakan software SPSS 17.0 for windows pada taraf signifikansi 0,05. Penelitian ini menghasilkan dua kesimpulan utama, yaitu ; pertama, terdapat pengaruh antara penggunaan pendekatan SLIM-n-BIL terhadap pemahaman konsep matematika karena didapatkan nilai $t_{\text {hitung }}$ sebesar 0,895 kurang dari $t_{\text {tabel }}$ yaitu 2,000 dengan Sig. 0,138 > $\alpha(0,05)$; kedua, pendekatan SLIM-n-BIL efektif dalam meningkatkan pemahaman konsep matematika peserta didik karena didapatkan nilai effect size sebesar 0,231 .
\end{abstract}

Kata kunci: kecerdasan majemuk, SLIM-n-BIL, pemahaman konsep matematika.

\begin{abstract}
The concept is one of the foundations of mathematics in the study of mathematics, if the concept is given to students not to good, then the result of learning and understanding of learners in the materials will be reduced. Mathematical concepts can be supplied with a variety of approaches so that learners are able to understand the material provided by the teacher, one of the mathematical learning approach is SLIM-n-BIL. The purpose of this study is to determine the effect and effectiveness of the approach using Slim-n-Bil to the understanding of the concept of junior high school math learners. This study used a quasi-experimental methods are implemented in SMP Mahardika with data retrieval through essay questions. Hypothesis testing is performed using the software SPSS 17.0 for windows at significance level of 0.05 . This study resulted in two main conclusions, namely; First, there is the effect of the use of the SLIM approach-n-BIL to the understanding of mathematical concepts as $t_{\text {count }}$ obtained for 0.895 less than the 2,000 $t_{\text {table }}$ with Sig. 0.138> $\alpha(0.05)$; second, SLIM approach-n-BIL effective in improving student understanding of mathematical concepts as values obtained effect size of 0.231 .
\end{abstract}

Keywords: multiple intelligences, SLIM-n-BIL, understanding of math concepts. 


\section{PENDAHULUAN}

Matematika merupakan ilmu universal yang mendasari perkembangan teknologi modern, mempunyai peran penting dalam berbagai disiplin ilmu pengetahuan dan mengembangkan daya pikir manusia. Perkembangan pesat dibidang teknologi informasi dan komunikasi dewasa ini dilandasi oleh perkembangan matematika dibidang teori bilangan, aljabar, analisis, teori peluang dan matematika diskrit. Untuk menguasai dan menciptakan teknologi di masa depan diperlukan penguasaan matematika yang kuat sejak dini. Hal ini diperkuat menurut Ruseffendi (1991: 260), yang menyatakan bahwa "matematika timbul karena pikiran-pikiran yang berhubungan dengan ide, proses dan penalaran".

Mata pelajaran matematika perlu diberikan kepada semua peserta didik mulai dari sekolah dasar, hal ini dimaksudkan untuk membekali para peserta didik dengan kemampuan berpikir logis, analitis, sistematis, kritis dan kreatif, serta memiliki kemampuan untuk bekerja sama.

Belajar matematika akan berhasil jika proses belajar mengajar berjalan dengan baik, yaitu melibatkan intelektual peserta didik secara optimal. Kegiatan belajar dapat tercapai jika faktor-faktor berikut ini dikelola dengan baik, yaitu peserta didik, pengajar, sarana dan prasarana serta penilaian. (Hudoyo, 1996: 6-7)

Kegiatan belajar mengajar tidak terlepas dari pendekatan pembelajaran. Pemilihan pendekatan pembelajaran sangat menentukan keberhasilan belajar dalam hal ini keberhasilan peserta didik. Pendekatan yang digunakan tidak sembarangan, melainkan sesuai dengan tujuan pembelajaran (Djamarah dkk, 2002: 177).

Salah satu kenyataan yang sering hadir pada pembelajaran matematika adalah bahwa pembelajaran matematika yang dilaksanakan dewasa ini lebih cenderung pada pencapaian target materi atau sesuai isi materi buku yang digunakan sebagai buku wajib dengan berorientasi pada soal-soal ujian nasional. Akibatnya kecerdasan yang dimiliki oleh peserta didik tidak tergali dengan baik.

Sejalan dengan hal tersebut, dalam kurikulum mengenai matematika terdapat standar kompetensi pada mata pelajaran matematika SMP yang terdiri dari empat aspek, yaitu bilangan, aljabar, geometri dan pengukuran, serta peluang dan statistika. Kemampuan dalam pembelajaran matematika yang diharapkan mencakup keempat aspek di atas adalah kemampuan pemahaman, penalaran dan pemecahan masalah, serta komunikasi matematik.

Dengan demikian, pembelajaran yang mengukur tingkat kecerdasan anak didik yang semata-mata hanya menekankan kecerdasan logika dan bahasa, pada pelajaran matematika perlu diubah (pembelajaran lebih berpusat pada guru dan aktivitas belajar masih didominasi oleh guru, pendekatan yang digunakan masih bersifat konvensional yakni klasikal).

Guru sebagai penyampai ilmu pengetahuan haruslah mampu mengajarkan matematika supaya lebih menarik, tidak membosankan, mudah dipahami dan mampu mengembangkan daya nalar serta kecerdasan yang dimiliki oleh peserta didik, sehingga peserta didik memahami konsep matematika dengan baik dan akhirnya mampu meningkatkan hasil belajar matematika serta motivasi untuk belajar matematika dengan baik. 
Pada dasarnya, kemampuan manusia untuk memahami matematika itu sama, hanya kecepatannya saja yang berbeda. Howard Gardner, seorang dosen Psikologi di Harvard School of Education merumuskan The Seven Types of Intelligence (7 tipe kecerdasan), yaitu :

1. Linguistic (cerdas dalam berbahasa);

2. Spatial-Visual (cerdas dalam menggambar atau membayangkan);

3. Interpersonal (cerdas dalam berinteraksi dengan sesama);

4. Musical (cerdas dalam bernyanyi atau memainkan alat musik);

5. Bodily-kinesthetic (cerdas dalam menggerakan badan/ tubuh);

6. Intrapersonal (cerdas dalam memahami diri sendiri atau merenung);

7. Logical mathematical (cerdas dalam berhitung).

Ketujuh kecerdasan ganda tersebut kemudian ditambah dengan satu kecerdasan "naturalist", yang kemudian oleh Bobbi de Porter dkk. disusun dalam bentuk singkatan yang mudah diingat, atau dalam istilah lain dikenal dengan titian ingatan SLIM-n-BIL.

Dalam pendekatan pembelajaran ini, peserta didik dalam hal ini adalah peserta didik yang memperoleh pendidikan dan pembinaan secara optimal diharapkan akan dapat mengembangkan potensi kecerdasannya seoptimal mungkin. Kegiatan belajar dan mengajar merupakan proses kegiatan yang tidak dapat dipisahkan dari pembelajaran, dan proses tersebut harus dilandaskan pada suatu sistem yang baik dengan memilih strategi, pendekatan, dan metode serta pendekatan pembelajaran yang sesuai dengan tingkat kemampuan peserta didik agar dapat menentukan keberhasilan peserta didik. Keberhasilan proses belajar dan mengajar dipengaruhi oleh beberapa faktor, diantaranya pemilihan pendekatan pembelajaran, minat peserta didik terhadap materi yang diajarkan dan peranan guru dalam mengatasi kesulitan belajar serta motivasi dari peserta didik itu sendiri untuk belajar dan memahami matematika.

Pemilihan pendekatan pembelajaran yang baik agar hasil yang optimal dapat diperoleh merupakan suatu hal yang penting. Karena hal ini dapat memotivasi peserta didik untuk mengembangkan pengetahuannya tanpa merasa bahwa materi yang diberikan oleh guru sangat menyulitkan dan membosankan. Berdasarkan hal inilah, seorang pendidik dan pengajar harus mampu memberikan motivasi yang besar kepada peserta didiknya agar dapat menerima materi yang disampaikan dengan baik.

Pemilihan pendekatan pembelajaran merupakan strategi guru dalam proses pembelajaran matematika hendaklah dapat merangsang dan melibatkan peserta didik secara aktif, baik secara fisik (psikomotor), intelektual (kognitif), dan emosionalnya (afektif) dalam belajar. Seperti yang diungkapkan oleh Hudoyo (1996), bahwa strategi yang diambil dalam rangka pembaharuan pendidikan saat ini hendaknya guru mampu melibatkan secara aktif dalam proses belajar mengajarnya sehingga dapat meningkatkan daya kreatifitas dan berpikir kritis serta dapat memperkuat motivasi mereka (peserta didik) untuk belajar.

Bertolak dari uraian di atas, maka penulis mengadakan penelitian mengenai efektivitas penggunaan pendekatan pembelajaran SLIM-n-BIL dalam peningkatan pemahaman konsep matematika pada peserta didik kelas VIII di SMP Mahardika Kecamatan Kresek Kabupaten Tangerang. 


\section{TINJAUAN PUSTAKA}

\section{Hakikat Belajar Matematika}

Banyak orang yang menyebutkan istilah belajar, diantaranya; dengan belajar semua dapat dilakukan, belajarlah sampai ke negeri Cina, belajarlah dari sebuah kegagalan, dan lainnya. Banyak buku dan para ahli mendefinisikan kata belajar atau batasan dengan yang berbeda-beda, namun pada umumnya mempunyai pengertian yang sama. Belajar merupakan hal yang penting dalam kehidupan manusia. Belajar juga merupakan proses dari perkembangan hidup manusia. Melalui belajar, manusia melakukan perubahan-kualitatif individu sehingga tingkah lakunya berkembang.

Hamalik (2009: 27) mendefinisikan belajar yaitu modifikasi atau memperteguh kelakuan melalui pengalaman (learning is defined as the modification or strengthening of behavior through experiencing)." karena semakin banyak seseorang belajar maka pengalaman yang diterima akan semakin besar dan akan memperteguh sikap dan kelakuannya pada kemudian hari. Definisi ini mengatakan bahwa tingkah laku seseorang akan berubah melalui pengalaman hidup yang didapatkan oleh orang tersebut, sebagaimana pepatah yang mengatakan experience is the best teacher yang artinya pengalaman adalah guru yang terbaik.

Definisi belajar yang lain diungkapkan oleh Djamarah (2002: 13) yang mendefinisikan tentang belajar, yaitu "serangkaian kegiatan jiwa raga untuk memperoleh suatu perubahan tingkah laku sebagai hasil dari pengalaman individu dalam interaksi dengan lingkungannya yang menyangkut kognitif, afektif dan psikomotor". Hal ini semakin memperkuat teori sebelumnya bahwa belajar berkaitan dengan pengalaman seseorang yang diterima pada pendidikan formal, informal dan non formal, sehingga memperoleh perubahan perilaku dalam hidupnya.

Belajar di dalam pendidikan formal tidak akan terlepas dari matematika, menurut Suriasumantri (2009: 190), "matematika adalah bahasa yang melambangkan serangkaian makna dari pernyataan yang ingin kita sampaikan. Lambang-lambang matematika bersifat artificial yang baru mempunyai arti setelah sebuah makna diberikan kepadanya".

Matematika sungguh bermanfaat dalam kehidupan di dunia ini, tidak ada hal yang tidak menggunakan matematika. Menurut James dan james yang dikutip oleh Gawatri U.R (2004: 1), "matematika adalah ilmu logika mengenai bentuk, susunan, besaran dan konsep-konsep yang saling berhubungan satu sama lainnya dengan jumlah yang terbagi ke dalam tiga bidang, yaitu; aljabar, analisis dan geometri”.

Berdasarkan uraian tersebut di atas, maka dapat disimpulkan bahwa belajar matematika adalah pengetahuan atau keterampilan yang dikuasai dan dimiliki oleh peserta didik setelah menerima pengalaman belajar matematika di sekolah berupa pengetahuan, pemahaman konsep, perhitungan dan pemecahan masalah tertentu. 


\section{Hakikat Pemahaman Konsep Matematika}

Pemahaman merupakan terjemahan dari istilah understanding yang diartikan sebagai penyerapan arti suatu materi yang dipelajari. Dalam matematika, konsep adalah suatu ide abstrak yang memungkinkan seseorang untuk menggolongkan suatu objek atau kejadian. Jadi pemahaman konsep adalah pengertian yang benar tentang suatu rancangan atau ide abstrak

Kemampuan pemahaman matematis adalah salah satu tujuan penting dalam pembelajaran, memberikan pengertian bahwa materi-materi yang diajarkan kepada peserta didik bukan hanya sebagai hafalan, namun lebih dari itu. Dengan pemahaman peserta didik dapat lebih mengerti akan konsep materi pelajaran itu sendiri. Pemahaman matematis juga merupakan salah satu tujuan dari setiap materi yang disampaikan oleh guru, sebab guru merupakan pembimbing peserta didik untuk mencapai konsep yang diharapkan.

Dalam penelitian ini, hasil belajar diperoleh peserta didik berdasarkan hasil tes pemahaman konsep berupa tes dengan bentuk soal uraian.

\section{SLIM-n-BIL}

Istilah kecerdasan atau intellegences bukanlah sesuatu yang baru bagi kita sebagai pendidik. Namun sejalan dengan perkembangan ilmu pengetahuan, ilmu tentang kecerdasan pun berkembang. Banyak ahli dari berbagai disiplin ilmu melakukan penelitian tentang otak manusia. Salah satunya adalah Prof. Howard Gardner, seorang ahli psikologi kognitif dari Universitas Harvard, meneliti tentang kecerdasan manusia. Ia mengatakan, "IQ tidak boleh dianggap sebagai tinggi rendah seperti tekanan darah manusia, dan kecerdasan seseorang tidak dapat diukur secara mutlak dengan tes-tes IQ". Menurutnya juga, tes IQ hanya mampu mengukur kemampuan seseorang dalam mengerjakan tes IQ tersebut saja. Selanjutnya, ia menemukan bahwa setiap orang memiliki beberapa kecerdasan, tidak hanya satu kecerdasan saja. Ia menyebutnya dengan kecerdasan ganda atau intelegensi ganda atau multiple intelligences, yang dimaksud dengan intelegensi ganda adalah kemampuan untuk memecahkan masalah atau menciptakan suatu produk yang bernilai dalam satu latar belakang budaya tertentu. Artinya, setiap orang jika dihadapkan pada satu masalah, ia memiliki sejumlah kemampuan untuk memecahkan masalah yang berbeda sesuai dengan konteksnya. Ini berarti setiap individu dapat mengembangkan seluruh kemampuannya secara maksimal.

Ada delapan jenis intelegensi yang dikemukakan oleh Howard Gardner, yaitu :

1. Spatial-visual ;

Intelegensi spatial-visual, yaitu kemampuan berpikir dalam citra dan gambar. Seperti kemampuan untuk membayangkan bentuk suatu objek.

2. Linguistic;

Intelegensi linguistic, yaitu kemampuan bahasa yang mencakup kemampuankemampuan berpikir dengan kata-kata, seperti kemampuan untuk memahami dan merangkai kata serta kalimat, baik lisan maupun tertulis.

3. Interpersonal ;

Intelegensi Interpersonal, adalah kemampuan berkomunikasi dan berinteraksi dengan orang lain (bersosialisasi). 
4. Musical ;

Intelegensi musical, adalah kemampuan berpikir dengan nada, irama dan melodi juga pada suara alam.

5. Naturalist ;

Intelegensi naturalist, adalah kemampuan untuk memahami gejala alam serta senang dengan nuansa alam dan isinya.

6. Bodily-kinesthetic;

Intelegensi bodily-kinesthetic, yaitu kemampuan yang berhubungan dengan gerakan tubuh, termasuk gerakan motorik otak yang mengendalikan tubuh seperti kemampuan untuk mengendalikan dan menggunakan anggota badan dengan mudah dan cekatan.

7. Intrapersonal ;

Intelegensi intrapersonal, adalah kemampuan untuk memahami diri sendiri, melakukan refleksi diri atau merenung.

8. Logical mathematical.

Intelegensi logis mathematical adalah kemampuan berpikir dalam penalaran atau menghitung, seperti kemampuan menelaah masalah secara logis, ilmiah dan matematis.

Kedelapan kecerdasan ganda tersebut kemudian disusun oleh Bobbi de Porter dkk. dalam bentuk singkatan yang mudah diingat, atau dalam istilah lain dikenal dengan titian ingatan SLIM-n-BIL.

Sebenarnya dalam melaksanakan proses belajar yang menggunakan SLIM-n-BIL ini tidaklah sesulit seperti apa yang dibayangkan, yang dibutuhkan hanyalah kreativitas dan kepekaan guru saja. Artinya setiap guru harus dapat berpikir secara terbuka. Ini berarti, seorang guru harus keluar dari paradigma pengajaran tradisional yang hanya mengutamakan kecerdasan bahasa dan logika saja serta harus mau menerima adanya perubahan dan harus juga memiliki kepekaan dalam melihat setiap hal yang dapat digunakan di lingkungan sekitar dalam menunjang proses belajar.

Mognesen (Rusmana, 2009: 12) menjelaskan bahwa kita belajar 10\% dari apa yang kita baca, 20\% dari apa yang kita dengar, 30\% dari apa yang kita lihat, 50\% dari apa yang kita lihat dan dengar, $70 \%$ dari apa yang kita katakan, 90\% dari apa yang kita katakan dan lakukan. Artinya seseorang bisa menyerap informasi paling banyak pada saat dia melakukan atau mempraktikan materi yang diterimanya.

Menurut Hernowo dan Nurdin (2005: 12), terdapat alasan untuk menerapkan pendekatan pembelajaran SLIM-n-BIL ini di dalam kelas, diantaranya para guru akan mendapatkan kesempatan untuk mengembangkan kegiatan pembelajaran yang inovatif yang relatif baru di dunia pendidikan. Sehingga perbedaan kemampuan yang dimiliki oleh peserta didik dapat diminimalisir dengan baik. Selain itu, dengan mengetahui adanya ragam dan kombinasi jenis kecerdasan pada peserta didik, maka guru dapat memberikan pilihan agar peserta didik dapat lebih memahami penjelasan yang diberikan oleh guru, diantara pilihan-pilihan yang dapat dilakukan adalah :

1. Memperkaya dan memupuk kecerdasan dominan dari tiap individu peserta didik; 
2. Membangkitkan dan memperkuat jenis kecerdasan yang dianggap lemah; dan

3. Memfasilitasi peserta didik dalam mendapatkan pengalaman tentang keberadaan semua jenis kecerdasan yang dimiliki oleh dirinya.

\section{METODE}

Untuk memecahkan suatu masalah, penggunaan suatu metode sangatlah penting. Sesuai dengan masalah yang hendak dipecahkan dan tujuan yang hendak dicapai serta hipotesis yang diajukan, maka penelitian ini menggunakan metode eksperimen yaitu dengan adanya perlakuan kepada objek penelitian. Sesuai dengan judul dan masalah yang ada, pelaksanaan penelitian ini menggunakan desain penelitian sebagai berikut :

Keterangan :

\begin{tabular}{|c|c|}
\hline A & B \\
\hline $\mathrm{Y}_{1}$ & $\mathrm{Y}_{2}$ \\
\hline
\end{tabular}
A : Kelompok eksperimen
B : Kelompok kontrol
$\mathrm{Y}_{1}$ : Pemahaman konsep matematika yang menggunakan pendekatan pembelajaran SLIM-n-BIL
$\mathrm{Y}_{2}$ : Pemahaman konsep matematika yang menggunakan pendekatan pembelajaran klasikal

\section{HASIL DAN PEMBAHASAN}

Pengujian Persyaratan Analisis

\section{Uji Normalitas}

Tabel 1. Ringkasan Hasil Uji Normalitas

\begin{tabular}{|c|c|c|}
\hline Kelompok Data & Asymp. Sig & Keterangan \\
\hline Eksperimen & 0,808 & Data berdistribusi normal \\
\hline Kontrol & 0,172 & Data berdistribusi normal \\
\hline
\end{tabular}

Dari tabel 1 dapat terlihat bahwa nilai Asymp. Sig untuk kelompok eksperimen dan untuk kelompok kontrol lebih besar dari $\alpha=(0,05)$, ini berarti distribusi nilai pada setiap kelas berdistribusi normal.

\section{Uji Homogenitas}

Tabel 2. Ringkasan Hasil Homogenitas

\begin{tabular}{|c|c|c|c|}
\hline $\begin{array}{l}\text { Levene } \\
\text { Statistic }\end{array}$ & dff & $\mathrm{df2}$ & Sig \\
\hline 2,266 & 1 & 58 & $\square, 138$ \\
\hline
\end{tabular}

\section{Pengujian Hipotesis}

Uji ini dilakukan untuk menguji hipotesis yang telah ada yaitu : 
$\mathrm{H}_{0}: \mu_{\mathrm{A} 1}=\mu_{\mathrm{A} 2} \quad$ (Tidak terdapat pengaruh penggunaan pendekatan pembelajaran SLIM-n-BIL dalam peningkatan pemahaman konsep matematika)

$\mathrm{H}_{1}: \mu_{\mathrm{A} 1} \neq \mu_{\mathrm{A} 2} \quad$ (Terdapat pengaruh penggunaan pendekatan pembelajaran SLIM-n-BIL dalam peningkatan pemahaman konsep matematika)

Tabel 3. Ringkasan Hasil Uji Hipotesis

Independent Samples Test

\begin{tabular}{|c|c|c|c|c|c|c|c|c|c|c|}
\hline & & \multicolumn{2}{|c|}{$\begin{array}{l}\text { Levene's Test for } \\
\text { Equality of } \\
\text { Variances }\end{array}$} & \multicolumn{7}{|c|}{ t-test for Equality of Means } \\
\hline & & \multirow[b]{2}{*}{$\mathbf{F}$} & \multirow[b]{2}{*}{ Sig. } & \multirow[b]{2}{*}{$t$} & \multirow[b]{2}{*}{ df } & \multirow[b]{2}{*}{$\begin{array}{l}\text { Sig. (2- } \\
\text { tailed) }\end{array}$} & \multirow[b]{2}{*}{$\begin{array}{c}\text { Mean } \\
\text { Difference }\end{array}$} & \multirow[b]{2}{*}{$\begin{array}{c}\text { Std. Error } \\
\text { Difference }\end{array}$} & \multicolumn{2}{|c|}{$\begin{array}{l}95 \% \text { Confidence } \\
\text { Interval of the } \\
\text { Difference }\end{array}$} \\
\hline & & & & & & & & & Lower & Upper \\
\hline \multirow{2}{*}{$\begin{array}{l}\text { Pemahaman_ } \\
\text { Konsep }\end{array}$} & $\begin{array}{l}\text { Equal variances } \\
\text { assumed }\end{array}$ & 2,266 & 0,138 & $\theta, 895$ & 58 & 0,374 & 5,333 & 5,959 & $-6,594$ & 17,261 \\
\hline & $\begin{array}{l}\text { Equal variances not } \\
\text { assumed }\end{array}$ & & & $\theta, 895$ & 56,011 & $\theta, 375$ & 5,333 & 5,959 & $-6,603$ & $17,27 \theta$ \\
\hline
\end{tabular}

Ringkasan hasil perhitungan uji nilai t pada tabel di atas menunjukkan nilai $\mathrm{t}_{\text {hitung }}=0,895$. Karena nilai $\mathrm{t}_{\text {hitung }}=0,895<\mathrm{t}_{\text {tabel }}(0,05)$ dengan $\mathrm{df}(58)=$ 2,000 maka $\mathrm{H}_{0}$ ditolak. Dengan kata lain bahwa terdapat pengaruh penggunaan pendekatan SLIM-n-BIL dalam peningkatan pemahaman konsep matematika.

Untuk melihat sejauh mana efekivitas penggunaan media ICT dalam pemahaman konsep matematika maka nilai t hitung $=0,895$ masukan ke dalam persamaan perhitungan effect size dan didapatkan nilainya yaitu sebesar 0,231 dan ini menunjukan bahwa tingkat efektivitasnya sedang (efektif).

\section{Keterangan :}

$$
\mathrm{ES}=\mathrm{t} \sqrt{\left(\frac{1}{\mathrm{~N} 1}+\frac{1}{\mathrm{~N} 2}\right)}
$$

$$
\begin{aligned}
& \mathrm{t} \quad=\text { Nilai } \mathrm{t} \text { hitung } \\
& \mathrm{N} 1=\text { Jumlah subyek kelompok eksperimen } \\
& \mathrm{N} 2=\text { Jumlah subyek kelompok kontrol }
\end{aligned}
$$

Kriteria untuk menetapkan harga ES adalah:

$\mathrm{ES} \leq 0,2$ harga efektivitas rendah (kurang efektif)

$0,2<$ ES $\leq 0,8$ harga efektivitas digolongkan sedang (efektif)

ES $>0,8$ efektivitas digolongkan tinggi (sangat efektif)

\section{Pembahasan}

Dari hasil penelitian ini didapatkan nilai $t_{\text {hitung }}(0,895)<t_{\text {tabel }}(2,000)$. Sehingga hipotesis awal diterima yaitu penggunaan pendekatan pembelajaran SLIM-n-BIL berpengaruh terhadap pemahaman konsep matematika peserta didik SMP. 
Nilai $t_{\text {hitung }}$ yang didapatkan dari proses perhitungan dimasukkan ke dalam rumus effect size (ES) untuk menentukan nilai efektivitasnya dan setelah dihitung didapatkan nilai ES sebesar 0,231. Berdasarkan kriteria yang ada maka nilai ES menunjukan bahwa penggunaan pendekatan pembelajaran SLIM-n-BIL efektif dalam meningkatkan pemahaman konsep matematika peserta didik.

Selain dari hasil uji hipotesis, dari hasil analisis deskriptif juga diperoleh hasil belajar matematika peserta didik yang belajar dengan pendekatan SLIM-nBIL memperoleh skor rata-rata sebesar 41,17, sedangkan pada kelompok peserta didik yang belajar dengan menggunakan pendekatan klasikal diperoleh skor ratarata 35,83 . Dari nilai rata-rata tersebut terlihat bahwa penggunaan pendekatan SLIM-n-BIL menjadikan nilai rata-rata matematika lebih tinggi dibandingkan yang menggunakan pendekatan klasikal.

Penggunaan pendekatan pembelajaran SLIM-n-BIL memiliki pengaruh dalam meningkatkan pemahaman konsep matematika peserta didik. Hal ini dikarenakan dalam proses pembelajarannya, pendekatan ini menekankan kepada cara belajar peserta didik. Peserta didik yang memiliki kebiasaan belajar dengan menggunakan musik, maka pada pendekatan ini guru menggunakan pemutar musik juga berupa notebook dan speaker dengan menggunakan musik klasik sebagai latar proses pembelajarannya. Selain menggunakan musik, pada pembelajaran dengan pendekatan SLIM-n-BIL ini peserta didik juga mengalami pembelajaran di luar kelas. Hal ini dikarenakan kecerdasan natural (alam) yang ada pada peserta didik harus diasah, salah satunya dengan mengadakan sesi refleksi di luar kelas. Kecerdasan yang lain, seperti bahasa, motorik (gerak tubuh), interpersonal, intrapersonal dapat terlihat dengan baik.

Penelitian yang dilakukan sebelumnya pada tahun 2009 tentang "efektivitas penggunaan model pembelajaran SLIM-N-BIL untuk meningkatkan prestasi dan motivasi belajar matematika peserta didik SMP" menghasilkan bahwa pembelajaran dengan pembelajaran SLIM-n-BIL lebih baik dan menyenangkan daripada pembelajaran klasikal dan mampu meningkatkan prestasi belajar serta motivasi belajar peserta didik, dan dalam penelitian ini mendapatkan hasil yang efektif dalam meningkatkan pemahaman konsep matematika pada peserta didik.

\section{PENUTUP}

\section{Simpulan}

Berdasarkan dari hasil pengujian hipotesis penelitian dan analisis pengolahan data dengan bantuan software SPSS 17.0 for windows pada bab V, maka hasil penelitian dengan judul "Efektivitas Penggunaan Pendekatan Pembelajaran SLIM-n-BIL dalam Peningkatan Pemahaman Konsep Matematika Bagi Peserta Didik" dapat disimpulkan sebagai berikut:

1. Terdapat pengaruh penggunaan pendekatan SLIM-n-BIL dalam peningkatan pemahaman konsep matematika pada peserta didik di SMP Mahardhika kecamatan Kresek, hal ini dikarenakan nilai Sig. $(0,138)>\alpha(0,05)$.

2. Penggunaan pendekatan SLIM-n-BIL efektif dalam meningkatkan pemahaman konsep matematika pada peserta didik di SMP Mahardhika kecamatan Kresek dengan hasil perhitungan effect size sebesar 0,231 (berkategori efektif). 
Saran

Saran yang dapat dikemukakan oleh peneliti adalah sebagai berikut :

1. Bagi para pembaca khususnya tenaga pendidik (guru); pembelajaran dengan pendekatan SLIM-n-BIL dapat dijadikan sebagai salah satu alternatif kegiatan pembelajaran yang menyenangkan dan variatif serta dapat diterapkan di kelas dalam usaha untuk meningkatkan hasil belajar matematika peserta didik.

2. Bagi penelitian yang akan datang dan tertarik dengan penggunaan pendekatan SLIM-n-BIL ini, hendaknya mengembangkan instrumen lain untuk materi ajar yang berbeda atau untuk kelas dalam jenjang pendidikan yang lain atau populasi yang tidak serupa dengan penelitian yang telah dilakukan pada penelitian kali ini.

\section{DAFTAR PUSTAKA}

Dimyati dan Mudjiono. 2006. Belajar dan Pembelajaran. Jakarta: PT Rineka Cipta.

Djamanah \& Zaid. 2002. Strategi Belajar Mengajar. Jakarta: PT Rineka Cipta.

E.T. Ruseffendi, 1990, Pengajaran Matematika Modern. Bandung: Tarsito.

Gawatri, dkk. 2004. Matematika untuk Tingkat I SMK. Jakarta: Yudhistira.

Hamalik, Oemar. 2009. Psikologi Belajar dan Mengajar. Jakarta: PT Bumi Aksara.

Harsanto, Radon. 2006. Pengelolaan Kelas Yang Dinamis. Jakarta : Grasindo.

Hernowo \& Nurdin. 2005. Bu Slim dan Pak Bil: Kisah tentang Kiprah Guru

"Multiple Intelligences" di Sekolah. Bandung: Mizan.

Hudoyo. 1996. Mengajar Belajar Matematika. Jakarta: Depdikbud Dirjen Dikti.

Muhibbin, Syah. 1997. Psikologi Pendekatan dengan Pendekatan Baru. Bandung: Remaja Rosdakarya.

Mulyasa, E. 2006. Menjadi Guru Professional Menciptakan Pembelajaran

Kreatif dan Menyenangkan. Bandung : Remaja Rosdakarya.

Ridwan, Sunarto H. 2007. Pengantar Statistika untuk Penelitian. Bandung: Alfabeta.

Rostiyah. 2001. Strategi Belajar Mengajar. Jakarta: Rineka Cipta.

Ruseffendi, ET. 1980. Pengajaran Matematika Modern Untuk Orangtua,

Murid, Guru dan SPG. Bandung: Tarsito

Rusmana, Indra Martha. 2009. Efektivitas Penggunaan Model Pembelajaran Slim-n-Bil Untuk Meningkatkan Prestasi dan Motivasi Belajar Matematika Peserta didik SMP. (Skripsi Pada Universitas Sultan Ageng Tirtayasa). Serang: (tidak diterbitkan)

Sadiman. 2002. Media Pendidikan. Jakarta: Raja Grafindo Persada

Suciati, dkk. 2005. Belajar dan Pembelajaran. Jakarta: Universitas Terbuka.

Sudjana, Nana. 2004. Penilaian Hasil Proses Belajar Mengajar. Bandung: PT Remaja Rosdakarya.

Suherman, dkk. 2001. Strategi Pembelajaran Matematika Kontemporer. Bandung: JICA-UPI.

Suherman, E. 2003. Evaluasi Pembelajaran Matematika. Bandung: JICA-UPI.

Sukmadinata, N.S. 2006. Metode Penelitian Pendidikan. Bandung: PT Remaja Rosdakarya. 
Surapranata, S. 2006. Analisis, Validitas, Reliabilitas dan Interpretasi Hasil Tes Implementasi Kurikulum 2004. Bandung: PT Remaja Rosdakarya. Suratman, D. \& Edi Tandililing. 2006. Efektifitas Pendekatan Reduksi Didaktik dalam Perkuliahan Geometri Analitik Datar dan Ruang (Gad / Gar) di Program Studi Matematika FKIP Untan. (proseding seminar ppd 2006 forum heds bidang ilmu pendidikan). Pontianak: Tidak diterbitkan.

Suriasumantri, Jujus S., 2009. Filsafat Ilmu (Sebuah Pengantar Populer). Jakarta: Pustaka Sinar Harapan.

Tim Penyusun. 2003. Kamus Besar Bahasa Indonesia. Jakarta: Balai Pustaka.

Uyanto, S. S. 2006. Pedoman Analisis Data dengan SPSS. Yogyakarta: Graha Ilmu. 